\section{TASHAWWUF TAHRIKI: Anti Korupsi}

\section{Arrafie Abduh}

Fakultas Ushuluddin dan Filsafat UIN Suska Riau

\section{Abstract}

Dynamic Shufism: Anticorruption: Dynamic shufism developts positive thinking and realistic behavior about of paradigm of the material, spiritual and moral. Shufis are convinced anticorruption. Corruption in Indonesia especially has been in a virus, savage cancer and serious condition and its dangers are out of ordering state and civil society life in the fields of politics (money politics), economy (legalling all ways obtain money and wealth) and law (manipulation of facts). Problem solving these fenomena, anticorruption movements have been done every where, either by an individual, the state or social organization, however, its result is not yet satisfactory. One of the effective methods (thariqah) according to dynamic shufism perspective to solve corruption (fasad or risywah in al-Qur'an and tradition term), collusion and nepotism stressing corruption is a polytheism (syirik). It is a pity, corruption is not yet awared or realized of one of polytheistic existence. In a polytheistic context necessary is interpreted by perspective of dynamic shufism. Polytheism (syirik) indicate a long time public and envirement corruption and bumankind suffering. Corrupters must be beavily punished and psychotherapy in order to be cured of a psychological disease and moral hazard or immoral.

Keywords: Tashawnuf Tabriki, anticorruption, polytheism and corruption.

\section{Pendahuluan}

Cinta, mahabbah, love, dalam bahasa Mandarin dan Jepang disebut "ai" dan korupsi, dalam term al-Qur'an disebut fasad dan dalam term hadis disebut risywah adalah dua kata yang hampir sama populernya. Cinta (mahabbah) adalah kata yang populer dalam perbincangan kalangan shufi, seperti Rabi'ah al-'Adawiyyah, al-Ghazali dan Ibnu 'Arabi. Di samping cinta, juga kata yang sering dilontarkan dalam perbincangan dalam masyarakat maupun oleh media massa adalah korupsi. Kelahiran tashawwuf dan konsepsi shufi pada awalnya jelas menentang korupsi, kolusi dan nepotisme terutama merebak dalam sistem pemerintahan.

Shufisme dinamis adalah konsep tashawwuf yang diangkat penulis, dalam mengaktualisasikan nilai-nilai mistisisme Islam yang diperbaharui melalui garis-garis tashawwuf ortodoks untuk mengembangkan sikap positif memaknai dunia, baik di dalam bidang politik, moral, spiritual maupun ekonomi dan seni, sebagai modifikasi shufisme yang menolak dunia, anti keduniaan dan menjauhi kehidupan materi. Tashawnuf tahriki diilhami oleh faham dinamisme Islam Muhammad Iqbal (1876-1938 M). Dalam syair-syairnya, ia memotivasi ummat Islam supaya bergerak dan jangan tinggal diam (pasiff. Intisari hidup adalah gerak, sedangkan hukum hidup adalah menciptakan, maka Iqbal berseru kepada ummat Islam supaya bangun dan menciptakan dunia baru. Begitu tinggi ia menghargai dinamika, sehingga ia menegaskan bahwa kafir yang aktif (kafir liberal menurut Emha Ainun Nadjib, ${ }^{1}$ ) lebih baik dari muslim yang suka tidur. Islam, tegas penyair filosof, shufi dan tokoh pembaharu yang berani mengkritik keras kekeliruan faham Ahmadiyyah di India saat itu, ${ }^{2}$ hlm. 14.

${ }^{1}$ Emha Ainun Nadjib, Kafir Liberal, (Yogyakarta: Proggress, 2005), Cetakan I,

${ }^{2}$ Ahmadiyyah adalah nama ajaran dan gerakan yang dimunculkan oleh Mirza Gulam Ahmad (1839-1908 M) di Qadian, Punjab, India. Ajaran dan gerakan ini, sebagaimana ajaran Babiyyah dan Bahaiyah yang timbul di Persia yang dicetuskan oleh Ali Muhammad Syirazi (w.1850 M) dan Mirza Husein Ali (1817-1892 M), oleh kalangan muslim sunni ortodoks dianggap menyimpang dari ajaran Islam yang sebenarnya. Ajaran-ajaran Ahmadiyyah yang umumnya dianggap menyimpang itu adalah, terutama, mengenai tiga hal; (1) penyaliban Nabi Isa as, (2) al-Mahdi yang dijanjikan akan muncul di akhir zaman (Mirza Gulam Ahmad itu sendiri), dan (3) tentang penghapusan kewajiban berjihad. Gulam Ahmad dinyatakan telah memproklamasikan dirinya sendiri sebagai al-Mahdi al-Muntazhar dan bahkan sebagai inkarnasi Isa al-Masih dan Muhammad bagi ummat Nashrani dan Muslim, di samping sebagai avatar (inkarnasi) Krishna bagi ummat Hindu dan Mesio Dorbhami bagi ummat Zoroaster. Menurut Ahmadiyyah, kepercayaan terhadap 
(dihujat keras juga di Indonesia terutama oleh MUI dan FPI), menolak konsep lama bahwa alam ini bersifat statis (jumud). Islam mempertahankan konsep dinamisme dan mengakui adanya gerak dan perubahan dinamis (dynamic dalam bahasa Inggris, tabriki dalam bahasa Arab, tung li sue dalam bahasa Mandarin dan kiryoku dalam bahasa Jepang) dalam hidup sosial, ekonomi, politik dan seni. Islam pada hakekatnya mengajarkan dinamisme. Al-Qur`an senantiasa menganjurkan pemakaian akal terhadap ayat (tanda) yang terdapat dalam alam, seperti pertukaran siang dan malam, bulan dan matahari. Orang yang tidak peduli dan tidak memperhatikan tanda-tanda itu tinggal buta terhadap masa mendatang. Konsep Islam mengenai alam adalah senantiasa berkembang (dinamis). Kemajuan serta kemunduran dibuat Tuhan silih berganti di antara bangsa-bangsa yang mendiami bumi. Ini mengandung arti dinamisme. ${ }^{3}$ Selain dari itu, Cara Kaya dan Menuai Surga adalah untuk pemberdayaan potensi ummat yang selama ini berada sebagian besar di bawah garis kemiskinan, dengan kiat-kiat yang lebih progresif untuk menjadi kaya, dengan tetap istiqamah pada prinsip-prinsip ajaran al-Qur`an dan hadis Nabi Muhammad Saw. ${ }^{4}$

Faktor utama yang melatarbelakangi lahirnya shufisme dinamis yaitu dari aspek internal dan eksternal perkembangan shufisme itu

dirinya sebagai al-Mahdi al-Muntazhar ini termasuk salah satu rukun iman, karena (1) kedatangannya di awal abad ke-14 Hijriyyah diramalkan oleh Nabi Muhammad Saw sendiri, dan (2) dia menyatakan dirinya telah menerima wabyu dari Allah Swt sejak tahun 1889. Alasan kedua itulah yang akhirnya menyebabkan dirinya diakui oleh para penganutnya sebagai Nabi. Beberapa tahun setelah Gulam Ahmad meninggal dunia tahun 1908, gerakan ini terpecah menjadi dua aliran yaitu Qadiani dan Labore, yang pertama tetap mengakui Gulam Ahmad sebagai Nabi, sedangkan yang kedua hanya mengakuinya sebagai pembaharu (mujaddid). Sir Muhammad Iqbal, Islam and Ahmadism, penerjemah Machnun Husein, Islam dan Ahmadiyyah, Jawaban terbadap Pertanyaan-Pertanyaan Pandit Jawaharlal Nehru, Jakarta: Bumi Aksara, 1991), Cetakan I, hlm. viii.

${ }^{3}$ Walfred. C. Smith, Modern Islam in India, (Lahore: Asyraf, 1963), hlm. 111.

4A. Qodri Azizy, Cara Kaya dan Menuai Surga, (Jakarta: Renaisan, 2005), Cetakan I, hlm. 5 sendiri. Secara internal kemunculan shufisme adanya sekelompok ummat Islam yang belum merasa puas dengan taqarrub ila Allab melalui ibadat shalat, shaum, zakat dan haji. Mereka ingin merasa lebih dekat lagi dengan Tuhan. Tujuan dari mistisisme, baik yang di dalam maupun yang di luar Islam ialah memperoleh hubungan langsung dan disadari dengan Tuhan, sehingga disadari benar bahwa seseorang berada di hadirat Tuhan. Intisari dari mistisisme, inklusif di dalamnya tashawwuf, adalah kesadaran adanya komunikasi dan dialog antara ruh manusia dengan Tuhan, dengan meditasi (kblawat, uəlah dan zubud) dan kontemplasi (dzikir, doa dan fikir). ${ }^{5}$ Dinamika yang terjadi dalam dunia shufisme sejak awal, biasanya diidentikkan dengan para zabid, qurra, dan nussak, yang hidupnya di sekeliling masjid, sampai masuknya pengaruh-pengaruh pemikiran asing (heterodoks), sehingga tashawwuf dianggap menyeleweng dari ajaran semula yaitu ajaran Nabi Muhammad Saw dan para sahabat, yang menyebabkan timbulnya reaksi keras dan memunculkan gerakan kembali kepada syariat. Namun, kombinasi itu muncul dalam pemikiran Junaid al-Baghdadi (w.910 M), artinya, Barangsiapa mengetahui ilmu fikih (syariat) dengan tiada mengetahui ilmu tashawwuf (hakekat), maka sesungguhnya orang itu fasik. Barangsiapa mengetahui ilmu tashawwuf dengan tiada mengetahui ilmu fikih, maka sesungguhnya orang itu zindik. Barangsiapa menghimpun antara fikih dan tashawwuf, maka sesungguhnya orang itu mencapai tahqiq. ${ }^{6}$

Tashawwuf dinamis adalah rekonstruksi sosio-moral, ekonomi dan seni. Walaupun shufisme dinamis cenderung bersifat puritan dan

${ }^{5}$ Harun Nasution, Falsafat dan Mistisisme dalam Islam, (Jakarta: Bulan Bintang, 1978), Cetakan II, hlm. 56, dan Harun Nasution, Islam Ditinjau dari Berbagai Aspeknya, (Jakarta: Universitas Indonesia, 1986), Jilid II Cetakan VI, hlm. 71, dan Rudolf Otto, Mysticism East and West, A Comparative Analysis of The Nature of Mysticism, A Discussion of the Nature of Mysticism, Focusing on the Similarities and Differences of its Two Principal Types, transleted by Bertha L.Bracey and Richenda C. Payne, (New York: The Micmillan Company, 1972), hlm. 13.

${ }^{6}$ M. Arrafie Abduh, Corak Tashawnuf Abdurrahman Shiddiq dalam SyairSyairnya, (Pekanbaru: Suska Press, 2008), Cetakan II, hlm. 27. 
aktivis, namun tidak sinkretis dan pasif (jumud). Zuhd, wara', wahdat alwijud dan al-insan al-kamil, dzikir dan fikir dalam rangka jïhad fi sabilillah, tetap eksis dihayati. Sehingga mungkin saja seorang shufi dinamis berjubah dan berjas atau safari dan berdasi, namun dalam hati sanubarinya terpancar sikap sederhana dan bersahaja, cahaya dzikir dan fikir yang terwujud dalam hidup yang anti korupsi dan kerja keras untuk meraih sukses. Ironis sekali, berbagai kasus korupsi yang dibongkar belakangan ini, mulai dari skandal dana taktis Komisi Pemilihan Umum, geger korupsi dana haji Departemen Agama (DAU), pesta dana APBD oleh sebagian anggota DPRD plus Bupati/wali kota, illegal logging, skandal Jamsostik, pembobolan BNI, hingga korupsi di tubuh Bank Mandiri.

Dalam konteks mistisisme Islam dinamis, korupsi merupakan tindakan yang bertentangan dengan prinsip shiddiq, amanah, tabligh dan fathanah. Korupsi dengan segala dampak negatifnya yang menimbulkan berbagai distorsi terhadap kehidupan masyarakat dan negara, dapat dikategorikan termasuk perbuatan fasad (korup), kerusakan di muka bumi, yang juga amat dikutuk Tuhan. Sayangnya, perbuatan korupsi tidak sampai disadari sebagai salah satu dari perwujudan syirik. Korupsi hanya disadari sebagai bentuk salah satu perbuatan jahat dan bertentangan dengan nilai-nilai kitab suci al-Qur'an dan Sunnah Rasulullah Saw sebagai dasar utama rujukan kaum shufi dan ajaran tashawwuf.

Di sinilah agaknya letak urgensinya shufisme dinamis dalam membentuk kesadaran sikap dan perilaku seseorang agar tidak tertipu memperoleh harta benda, kekayaan, jabatan dan kedudukan, dengan sikap tamak, rakus dan illegal. Shufisme dinamis juga berperan sebagai upaya preventif agar seseorang sadar untuk tidak berperilaku menyimpang dalam meraih harta kekayaan duniawi.

\section{Pengertian Korupsi}

Al-Qur'an menggunakan term fasad (corruption dalam bahasa Inggris, fu pai te dalam bahasa Mandarin dan fuhai dalam bahasa Jepang) dalam makna merusak, antara lain yang terpenting terdapat dalam surah al-Baqarah ayat 11 dan 12, dijelaskan Tuhan larangan berbuat kerusakan (la tufsidu fi al-ardhi) dan perbuatan yang seolah-olah membuat perbaikan di muka bumi padahal mereka melakukan perusakan (al-mufsidun), dianggap sebagai ciri munafik (hipokrit). Dalam surah al-A'raf ayat 127 adalah konteks rekaman dialog Fir'aun dengan pembesar-pembesar kaumnya dimana kata kerja liyufsidu fi alardhi digunakan untuk mengindikasikan kemungkinan ajaran yang dibawa Nabi Musa merusak kewibawaan Fir'aun. Dalam surah alSyu'ara ayat 152 diceritakan bahwa kaum Tsamud mendustakan Nabi Saleh. Nabi Saleh menyeru kaumnya agar tidak mengikuti mereka yang melewati batas, yaitu merusak (yufsiduna fi al-ardhi) di muka bumi dan tidak memperbaikinya. Dalam surah al-Naml ayat 48 punya konteks yang sama dengan surah al-Syu'ara ayat 152 yaitu pelajaran dari kaum Nabi Saleh yang merusak di muka bumi (yufsiduna fi al-ardhi). Konteks surah al-Qashash ayat 77 menjelaskan ketidaksukaan Tuhan terhadap Qarun yang suka merusak di bumi (al-mufsidina). Sedangkan surah alFajr ayat 12 memiliki konteks peringatan Tuhan kepada ummat Nabi Muhammad Saw yang membuat kerusakan di negeri yang nasibnya akan seperti mereka yang menentang kepada para nabi terdahulu.

Perbuatan merusak kalau dikaitkan dengan ayat-ayat al-Qur`an di atas termasuk ke dalam merusak di muka bumi terutama terhadap sesama manusia dan alam. Terhadap manusia semua aktivitas manusia baik ekonomi, sosial maupun politik, misalnya, surah al-Muthaffifin ayat 1-5, mengecam keras dan diancam dengan siksa yang sangat pedih bagi mereka yang mengurangi timbangan (takaran) dalam melakukan aktivitas perdagangan (jual beli). Terhadap alam, tindakan manusia yang dapat menimbulkan masalah, baik bagi manusia maupun alam semesta itu sendiri termasuk ke dalam tindak korupsi, seperti banyak kasus illegal logging (pembalakan liar) dan penebangan kayu illegal dalam beberapa dekade ini di tanah air, khususnya di bumi Melayu (Riau) ini, telah mengakibatkan pencemaran udara yang massif karena pembakaran hutan di musim kemarau (menimbulkan kabut 
asap sampai ke negara jiran, Malaysia dan Singapura), angin puting beliung dan longsong yang merusak banyak rumah dan banjir bandang dimana-mana di musim hujan yang merusak sarana transfortasi dan komunikasi. Padahal al-Qur`an mengingatkan, kerusakan di muka bumi, di darat (udara) dan di laut akibat ulah tangan usil manusia (alRum ayat 41). Perbuatan fasad (korup), kerusakan di muka bumi tersebut amat dikutuk Tuhan. Perbuatan korupsi itu dalam perspektif shufisme dinamis disadari sebagai salah satu dari perwujudan syirik. Masdar Farid Mas'udi, salah seorang Pengurus Besar Nahdhat al'Ulama memfatwakan tindak pidana korupsi sama dengan tindak pidana birabah (perampokan) atau bentuk pencurian besar, yang pelakunya dalam fikih Islam harus diberi hukuman mati, bahkan korupsi lebih jahat dari terorisme, karena tindak terorisme membunuh rakyat sekaligus, sementara tindak korupsi membunuh rakyat secara perlahan namun pasti. ${ }^{7}$ Agenda pemberantasan korupsi di tanah air tidak dilakukan seradikal di negeri tirai Bambu (Cina) yang dikenal dengan semboyan Peti mati untuk koruptor, tegar Zhu Rongji sat dilantik sebagai Perdana Menteri bulan Maret $1998 .^{8}$

Syirik bukan saja menyangkut aspek kepercayaan kepada Tuhan, tetapi juga muncul dalam kehidupan sosial, ekonomi dan politik, salah satu contohnya adalah pengkultusan terhadap harta benda yang didapat dengan menghalalkan segala cara bermuara kepada hasil perilaku korupsi. Al-Qur`an menjelaskan bahwa syirik (syirk) bukan saja mengacu kepada penyembahan patung-patung atau berhala (alAnbiya ayat 2), tetapi juga benda-benda mati (al-Nisa` ayat 117), makhluk halus (al-An'am ayat 100), tokoh-tokoh yang dianggap mempunyai esensi ketuhanan (al-Nisa` ayat 171, al-Maidah ayat 116 dan al-Taubah ayat 31), penyembahan terhadap nafsu termasuk yang ada di dalam diri manusia itu sendiri (al-Furqan ayat 43).

${ }^{7}$ Buletin Anti Korupsi, Partnership, Desember 2004, hlm. 7.

${ }^{8}$ Koran, Kompas, 25 Mei 2003.
Dalam term hadis, korupsi diungkapkan dalam bentuk risywah (suap menyuap). Salah satu hadis yang dianggap lengkap dan dijadikan rujukan adalah riwayat Imam Ahmad ibnu Hanbal, dari Tsauban, ia berkata bahwa Rasulullah Saw melaknat penyuap (al-rasyz), penerima suap (murtasyi) dan perantaranya (al-raisy ya'ni al-ladzi yamsyi baynabuma) yaitu orang yang menghubungkan antara keduanya. ${ }^{9}$ Risywah adalah suap menyuap yang dilakukan oleh dua pihak yang sama-sama aktif dan berkepentingan. Si penyuap berkepentingan mendapatkan sesuatu keuntungan yang lebih besar atau terhindar dari belitan hukum. Sedangkan si penerima suap berkepentingan mendapatkan imbalan, baik materi maupun nonmateri dengan cara illegal, menyahlahgunakan wewenang atau jabatan dan melanggar hukum. Risywah (rasywab atau rusywah) adalah suap menyuap untuk mempengaruhi sebuah keputusan agar menguntungkan pihak tertentu dan sebaliknya merugikan pihak lain. Al-Jurjani mendefinisikan risywah sebagai ma yu'tha liibthali haqqin aw liihqaqi bathilin. ${ }^{10}$ Orang yang menyuap disebut al-rasyi, yang meminta atau menerima suap disebut al-murtasyi dan perantaranya disebut al-raisy. Ditinjau dari segi intensitas kasus korupsi, maka suap menyuap termasuk kasus yang paling tinggi dan sering terjadi sehingga korupsi sering dimaknai risywah.

${ }^{9}$ Ahmad ibnu Hanbal, Musnad Ahmad, (Beirut: Dar al-Kutub al-'Tlmiyyah, 1412 H/1992 M), nomor hadis 21365. Dalam versi lain, Rasulullah bersabda yang diriwayatkan oleh Imam Ahmad juga (hadis ke 8670), La'ana Allabu al-rasyi wa almurtasyi fi al-bukm. Hadis ini juga diriwayatkan oleh Abu Dawud, Sunan Abi Dawnd, (Beirut: Dar al-Hadis, 1393 H), Juz IV, hlm. 10, dan Ibnu Majah, Sunan Ibnu Majah, muhaqqiq Muhammad Fuad 'Abd al-Baqi, (Beirut: Dar al-Ihya`al-Turats al-'Arabi, t.t.), Juz II, hlm. 776. Dalam suatu hadis lain, Rasulullah Saw bersabda, La'natu Allabi 'ala al-rasyi wa al-murtasyi, diriwayatkan oleh Ahmad ibnu Hanbal dan Ibnu Majah. Dalam riwayat Imam Ahmad ibnu Hanbal nomor hadis 2289, sedangkan dalam riwayat Ibnu Majah nomor hadis 2304

${ }^{10}$ Ali ibnu Muhammad al-Jurjani, Kitab al-Ta'rifat, (Beirut: Maktabah Lubnan, 1978), hlm. 116, dan Muhammad Abdu al-Rauf al-Munawi, al-Tawqif 'ala Mubimmati al-Ta'rif, (Beirut: Dar al-Fikr, 1410 H/1990 M), hlm. 365. 
Kata korupsi secara etimologis berasal dari kata corruptio (Latin) sebenarnya sudah dipakai sejak zaman para filosof Yunani kuno. Aristoteles (367-322 s.M), misalnya, memakai kata itu dalam konteks falsafat alamnya, lebih berarti perubahan, meski punya warna penurunan. Dalam arti ini, secara semantis kata korupsi masih jauh dari kekuasaan, apalagi uang, ${ }^{11}$ sebagai sumber korupsi. Korupsi berasal dari kata latin corruptio atau corruptus. Corruptio berasal dari kata Latin yang lebih tua yaitu corrumpere. Dari bahasa Latin itulah kemudian menyebar dalam bahasa Eropa, seperti corruption/corrupt (Inggris), corruption (Perancis-Jerman), corruptie/koruptie (Belanda) yang berarti palsu, suap dan busuk. Dari bahasa Belanda (yang menjajah Indonesia 350 tahun) inilah kata itu masuk dalam khazanah bahasa Indonesia menjadi korupsi. ${ }^{12}$ Dalam Kamus Umum Bahasa Indonesia dan Kamus Bahasa Indonesia Kontemporer, korupsi berasal dari kata korup yang berati busuk, palsu, dapat disuap, tidak bermoral, kebejatan dan ketidakjujuran. Korup juga berarti dapat disogok, menyelewengkan uang atau barang milik perusahaan atau negara, menerima uang dengan menggunakan jabatan untuk kepentingan pribadi, penyelewengan atau penggelapan uang negara atau perusahaan sebagai tempat seseorang bekerja untuk keuntungan pribadi atau orang lain, koruptor adalah orang yang melakukan korupsi, dan koruptif adalah budaya yang koruptif harus diberantas secara

${ }^{11}$ Al.Andang L.Binawan, editor, Korupsi Kemanusiaan, Menafsirkan Korupsi (dalam) Masyarakat, (Jakarta: Kompas Media Nusantara, 2006), Cetakan I, hlm. xii. ${ }^{12}$ Komisi Pemberantasan Korupsi, Mengenali dan Memberantas Korupsi, (Jakarta: KPK, 2006), hlm.12 dan 4. tuntas. ${ }^{13}$ Corrupt dalam bahasa Mandarin adalah fu pai te atau than $u$ te dan dalam bahasa Jepang adalah daraku, oshoku atau fubai. ${ }^{14}$

Korupsi dalam kamus bahasa Arab baru ditemukan dalam kamus-kamus modern seperti Hans Wehr dan al-Mawrid, temasuk kamus Arab-Indonesia, al-Munawmir. Padanan kata korupsi diambil dari kata risywah. Dalam al-Munawwir kata risywah dimaknai uang suap. Kata serupa dimaknai dalam al-Mawrid sebagai penyuapan dan korupsi, namun dalam Hans Wehr, risywah tidak saja dimaknai sebagai penyuapan (bribery), tetapi juga korupsi (corruption) dan ketidakjujuran (dishonesty). ${ }^{15}$

Secara terminologis, seperti halnya semua gejala dan anomali sosial yang krusyial (musykil), korupsi hampir tidak dapat dirumuskan dalam satu kalimat yang pasti dan singkat. Kemungkinannya adalah membuat deskripsi yang rasional mengenai gejala tersebut agar dapat dipisahkan dari fenomena lain yang bukan korupsi. Korupsi juga diartikan sebagai tindakan menyelewengkan uang atau barang milik perusahaan, lembaga atau negara, menerima uang dengan memanfaatkan jabatan untuk kepentingan pribadi. Korupsi juga berarti kebejatan moral, penyakit jiwa, tidak normal, ketidakjujuran dan penyimpangan dari kesucian yang perlu dipsikoterapi shufistik. Dalam perkembangannya di Indonesia korupsi terjadi dalam berbagai bentuk. Setidaknya korupsi terjadi dalam tiga pemaknaan yaitu (1)

13J.S.Badudu dan Sutan Mohammad Zain, Kamus Umum Bahasa Indonesia, (Jakarta: Pustaka Sinar Harapan, 1994), Cetakan I, hlm. 720, dan Peter Salim dan Yenny Salim, Kamus Bahasa Indonesia Kontemporer, Jakarta: Modern English Press, 1991), hlm. 773.

${ }^{14}$ Yan Tirtobisono, Kamus Inggris-Mandarin-Indonesia, (Surabava: Indah, 1996), hlm.63, dan M. Saleh Masodang dan JB. Andyana, Kamus Umum Indonesia-Jepang, (Bandung: Pioner Jaya, November 1986), hlm. 76.

${ }^{15}$ Hans Wehr, A Dictionary of Modern Written Arabic, Beirut: Libraire du Liban, 1980), Cetakan III, hlm. 342, Rohi Baalbaki, al-Mawrid, A Modern ArabicEnglish Dictionary, (Beirut: Dar el-Ilm Lilmalayin, 2000), hlm. 585, dan A. W. Munawwir, Kamus al-Munawnir Arab-Indonesia Terlengkap, (Krapyak: Pondok Pesantren al-Munawwir, 1984), hlm. 537. 
korupsi dalam pengertian terendah yakni tindakan pengkhianatan terhadap kepercayaan (betrayal of trust), (2) korupsi dalam tingkat menengah yaitu semua tindakan penyalahgunaan kekuasaan (abuse of power) walaupun pelakunya tidak mendapatkan keuntungan langsung secara material, (3) korupsi yang paling akut (parah) adalah penyalahgunaan kekuasaan untuk mendapatkan keuntungan material yang bukan haknya (material benefit). Justru itu, korupsi dapat dimaknai dengan penggelapan uang negara atau perusahaan dan sebagainya untuk kepentingan pribadi atau orang lain. ${ }^{16}$ Untuk mendapatkan deskripsi yang lebih komprehensif tentang korupsi, dijelaskan sembilan karakteristik tindak korupsi, (1) suatu pengkhianatan terhadap kepercayaan, (2) penipuan terhadap badan pemerintah, lembaga swasta atau masyarakat umum, (3) dengan sengaja melalaikan kepercayaan umum untuk kepentingan khusus, (4) dilakukan dengan rahasia kecuali dalam kondisi dimana orang-orang yang berkuasa atau bawahannya menganggap tidak perlu, (5) melibatkan lebih dari satu orang atau pihak, (6) adanya kewajiban dan keuntungan bersama dalam uang, barang atau lainnya, (7) terpusatnya kegiatan (korupsi) pada mereka yang dapat mempengaruhinya, (8) adanya usaha untuk menutupi perbuatan korupsi dalam bentuk pengesahan hukum, dan (9) menunjukkan fungsi ganda yang kontraproduktif pada mereka yang melakukan korupsi. ${ }^{17}$

Oleh karena itu, essensi korupsi adalah pencurian melalui penipuan, penyalahgunaan kekuasaan dan wewenang dalam situasi mengkhianati kepercayaan. Merujuk kepada definisi Komisi Pemberantasan Korupsi, pemberantasan korupsi adalah serangkaian tindakan untuk mencegah dan menaggulangi korupsi melalui upaya koordinasi, supervisi, monitoring, penyelidikan, penuntunan dan pemeriksaan di sidang pengadilan dengan peran serta masyarakat

16Leden Marpaung, Tindak Pidana Korupsi, (Jakarta: Djambatan, 1989), hlm. 5.

${ }^{17}$ Syed Husein Alatas, Korupsi; Sifat, Sebab dan Fungsi, (Jakarta: Dzikrul Hakim, 1997), hlm. 87. berdasarkan peraturan perundang-undangan yang berlaku. Dengan demikian maka pemberantasan korupsi mencakup tiga unsur utama yaitu pencegahan (anti korupsi atau preventif), penindakan (penanggulangan, kontrakorupsi atau represif) dan peran serta masyarakat (partisipatif). ${ }^{18}$

Awal Desember 1967 berdiri sebuah lembaga bernama Tim Pemberantasan Korupsi. Lembaga ini redup tanpa catatan prestasi yang luar biasa. Tiga tahun kemudian, tepatnya 15 Agustus 1970 dibentuk sebuah Komite Anti Korupsi. Lalu, pada September 1977 muncul Operasi Penertiban. Lembaga atau badan sejenis kemudian lahir dan muncul silih berganti. Di era pemerintahan Presiden Gusdur (Abdurrahman Wahid) dibentuk Tim Gabungan Pemberantasan Tindak Pidana Korupsi. ${ }^{19}$ Undang-Undang, Keputusan Presiden, Instruksi Presiden dan Peraturan Pemerintah tentang pemberantasan tindak pidana korupsi dan Kerjasama antara Komisi Pemberantasan Korupsi dengan Kejaksaan R.I. dalam Rangka Pemberantasan Tindak Pidana Korupsi, Keputusan Bersama Ketua KPK dan Jaksa Agung R.I., telah banyak dikeluarkan, seperti (1) Pengesahan Konvensi Perserikatan Bangsa-Bangsa anti Korupsi tahun 2003, UndangUndang R.I. nomor 7 tahun 2006, (2) Perubahan atas UndangUndang R.I. nomor 20 tahun 2001, (3) Komisi Pemberantasan Tindak Pidana Korupsi, Undang-Undang R.I. nomor 30 tahun 2002, (4) Penyelenggara Negara yang Bersih dan Bebas dari Korupsi, Kolusi dan Nepotisme, Undang-Undang R.I. nomor 28 tahun 1999, (5) Perlindungan Saksi dan Korban, Undang-Undang R.I. nomor 13 tahun 2006, (6) Komisi Pemeriksa Kekayaan Penyelenggara Negara, Keppres R.I. nomor 81 tahun 1999, (7) Percepatan Pemberantasan Korupsi, Inpres R.I. nomor 5 tahun 2004, (8) Tim Koordinasi

${ }^{18}$ Komisi Pemberantasan Korupsi, Mengenali dan Memberantas Korupsi, (Jakarta: KPK, 2006), hlm. 26

${ }^{19}$ Didin S. Damanhuri, Korupsi, Reformasi dan Masa Depan Ekonomi Indonesia, (Jakarta: Lembaga Penerbit Fakultas Ekonomi Universitas Indonesia, 2006), hlm. vi. 
Pemberantasan Tindak Pidana Korupsi, Keppres R.I. nomor 11 tahun 2005, (9) Kerjasama antara Komisi Pemberantasan Korupsi dengan Kejaksaan R.I. dalam Rangka Pemberantasan Tindak Pidana Korupsi, Keputusan Bersama Ketua KPK dan Jaksa Agung R.I. nomor Kep111212002, nomor Kep-Iaij.a11212005, (10) Peraturan Pemerintah nomor 71 dan nomor 19 tahun 2000, dan (11) Peraturan Pemerintah R.I. nomor 65, 66, 67 dan 68 tahun 1999,20 namun pelaku korupsi masih merajalela dan belum membuat jera para koruptor kakap.

Praktek korupsi di Indonesia, seperti juga umumnya negaranegara berkembang di Asia dan Afrika, telah dikembangbiakkan secara sistematis dan sophisticated semenjak masuknya kekuatan kolonialis. Pembiasaan praktek korupsi ini diiringi dengan proses pelemahan gerakan perlawanan kerakyatan dan eksploitasi kekayaan negara terjajah. Selain dari itu, praktek korupsi juga berjalan seiring dengan penghilangan secara terorganisir praktek-praktek birokrasi lokal yang potensial. Dalam banyak kasus hampir dalam segala bidang dan sektor pemerintahan dan pembangunan terlibat tindak korupsi, terutama kasus-kasus tentang pilkada secara langsung akhir-akhir ini diwarnai dengan berbagai praktek kotor money politics untuk membiayai tim sukses calon masing-masing dengan memanfaatkan akses-akses decision makers di daerah dan memanipulasi pengalokasian dana anggaran pada APBD. Tidak jarang terjadi, pos anggaran yang pada mulanya dialokasikan untuk membangun kepentingan infrasrtuktur dan kesejahteraan masyarakat, diubah dan disulap menjadi kepentingan praktek negosiasi antara dua belah pihak. Cara yang ditempuh kadangkala berlandaskan pada kesepakatan antara pihak eksekutif, legislatif dan yudikatif di dalam rapat-rapat resmi. Eksesnya, konflik dalam pilkada akan lebih kuat. Berdasarkan penelitian LP3ES mengenai konflik yang terjadi di daerah, dalam kurun waktu 19972002 tejadi 409 konflik etno komunal, 55 konflik antara negara dan masyarakat serta 36 konflik disebabkan kesenjangan ekonomi

${ }^{20}$ Redaksi Penerbit Asa Mandiri, Undang-Undang Pemberantasan Tindak Pidana Korupsi, (Jakarta: Asa Mandiri, 2007), Cetakan III, hlm. v. masyarakat. Ada sekitar 15 kabupaten/kota dari 14 provinsi yang potensial timbul konflik dalam pelaksanaan pilkada, di antaranya daerah Ambon, Maluku Utara, Poso dan Ternate. ${ }^{21}$

Korupsi juga menjalar dalam sektor perpajakan dan privatisasi Badan Usaha Milik Negara. Kedua institusi state income generating ini, selayaknya jika dilaksanakan secara transparan, maka negara hampir tidak lagi tergantung kepada pinjaman dan hutang luar negeri untuk menjamin kelancaran roda pemerintahan dan akselerasi pembangunan dalam semua bidang dan sektor. Namun, kenyataannya justru kedua aktivitas itu menjadi arena membagi kue (rezki) yang hanya menggemukkan para pejabat dan penyelenggara pemungutan pajak dan privatisasi. Seolah-olah, pemungutan negara berupa pajak dan proses pemberdayaan BUMN dengan cara privatisasi adalah kesempatan emas untuk mendulang keuntungan pribadi dengan mengatasnamakan kepentingan rakyat dan program negara.

Sangat ironis memang, korupsi yang melanda dunia peradilan dan penegakan hukum (hakim, jaksa, pengacara dan polisi). Dunia peradilan belum banyak mengindikasikan perubahan kinerja dan keberpihakan kepada keadilan yang sesungguhnya secara signifikan. Idealnya, peradilan adalah benteng terakhir orang-orang mencari dan menemukan keadilan dan kebenaran. Tetapi dalam prakteknya, para personil yang terlibat di lembaga tersebut, jarang terpanggil hati nuraninya untuk memenuhi tugas dan kewajiban dengan tulus dan tanpa pamrih. Bahkan, misi mereka tampaknya memelihara dan menjadi bagian dari lembaga broker perkara (makelar kasus). Advokasi dalam proses yurisdiksi dapat dilakukan melalui tindakan hukum yang dilakukan oleh masyarakat untuk menggugat kebijakan pemerintah melalui class action, legal standing dan citizen law suit. Contoh menarik adalah diakuinya gugatan legal standing oleh Solidaritas Anti Korupsi (SORAK) Aceh. Gugatan SORAK terhadap praktek korupsi

${ }^{21}$ Achmad Zainuri, Akar Kultural Korupsi di Indonesia, (Depok: CV.Cahaya Baru Sawangan, 2007), hlm. 97. 
yang dilakukan oleh Gubernur Aceh (Abdullah Puteh) diakui dan diterima oleh majelis hakim. Meskipun, vonis hakim menolak materi gugatan SORAK, setidaknya keputusan majelis hakim untuk mengakui hak masyarakat dalam legal standing akan menjadi yurisprudensi bagi gugatan serupa yang akan dilakukan oleh kelompok masyarakat lain, ${ }^{22}$ terutama kasus-kasus illegal logging yang marak terjadi.

Selain dari itu, praktek korupsi di Badan Urusan Logistik telah menyeret setidaknya para elit dan pelaku politik lintas era dan zaman. Jika dicermati lebih intensif, korban nyata dari korupsi Badan Urusan Logistik adalah jutaan petani di berbagai pelosok. Tentu saja, ini merupakan suatu hal yang paradoksal. Hampir tidak ada elit penguasa yang berpidato, kecuali mengatasnamakan penyejahteraan rakyat petani.

Empat faktor dominan yang menyebabkan praktek korupsi dan semakin diterimanya korupsi sebagai bagian kultur kehidupan seharihari yaitu faktor historis, ekonomis, sosio-kultural dan politik. Sejarah membuktikan bahwa terdapat komunitas tertentu yang merasa bahwa tatanan permerintahan, ekonomi, sosial dan politik yang diciptakan dengan model eksploitatif tidak layak untuk mendapatkan legitimasi moral untuk dipatuhi dan ditaati. Cara yang memungkinkan untuk dilakukan dengan menolak membayar pajak dan upeti dalam bentuk apapun dan bahkan dengan cara mengasingkan diri dan mengisolasikan komunitasnya secara sosial untuk membuktikan kontra loyalitas dan resistensinya. Cara memerintah semacam itu masih dirasakan sampai saat ini.

Dampak dari kondisi di atas, para elit tetap dengan strategi korupsinya jika memerintah, sementara massa grass root (akar rumput) bersikap kurang peduli dan skeptis. Massa akar rumput merasa tidak memiliki dan secara diam-diam atau terbuka, dengan ekspresi demonstrasi yang destruktif dan anarkis, umpamanya, mereka

22Danang Widoyono, dkk., Saatnya Warga Melawan Korupsi; Citizen Report Card untuk Pendidikan, (Jakarta: Indonesia Corruption Watch, 2006), Cetakan I, hlm. 72. membangun pola destruktif atas sistem itu dengan cara yang mirip dengan pembangkangan sistem. Hal ini tentu saja tidak bisa dipisahkan dari managemen pemerintahan warisan kolonial. Perubahan paling menyolok dalam pergantian rezim di Indonesia, dari era otoriter Orde Baru ke periode reformasi, baru sebatas perubahan mekanisme rekrutmen penguasa. Bila sebelumnya direkrut lewat pemilu terkontrol dan penuh manipulasi, kini dipilih melalui pemilu multipartai yang bebas, adil dan jujur. Perubahan prosedur suksesi kekuasaan semata, terbukti, menurut A.Zainury, tidak otomatis mampu membabat habis tradisi korupsi yang diwariskan rezim absolut sebelumnya. Alih-alih steril korupsi, yang berkembang justru improvisasi modus baru menyedot dana negara. Rapor tahunan Indonesia menurut Indeks Persepsi Korupsi Transparansi Internasional masih terus memprihatinkan. Dari ratusan negara yang disurvei, Indonesia selalu menempati posisi barisan terburuk korupsinya. Persepsi tingkat korupsi ini digali dari para pelaku bisnis, akademisi dan analis resiko. Dari skor antara satu (paling korup) sampai 10 (paling bersih), Indonesia hanya mampu meraih nilai tertinggi 2,72 (tahun 1997).23

Korupsi di Indonesia saat ini telah menjadi virus dan kanker ganas yang penyebarannya sangat akut sehingga sulit dan berat untuk ditanggulangi, harus melibatkan berbagai elemen dan komponen yang komit dengan anti korupsi. Bahkan seringkali praktek korupsi dianggap biasa sebagai moral yang bejat (moral hazard) manakala tatanan nilai yang ada telah terkontaminasi dengan budaya yang tidak dilandasi nilai etik dan moral. Berdasarkan data dari Transparansi Internasional tahun 2004 dijelaskan bahwa Indonesia menempati angka kelima besar dari 146 negara, sejajar dengan Anggola, Pantai Gading, Georgia, Tajikistan dan Turkmenistan. ${ }^{24}$ Tahun 2006 dinyatakan bahwa parlemen di Indonesia, baik di tingkat pusat amupun daerah, merupakan lembaga terkorup, baru kemuydian

${ }^{23}$ Achmad Zainury, Akar Kultural Korupsi..., hlm. 1.

${ }^{24}$ Surat Kabar, Kompas, tanggal 21 Oktober 2004. 
pengadilan, kejaksaan dan polisi. ${ }^{25}$ Awal Maret 2005 lembaga hampir serupa Political and Economic Risk. Consultancy mengumumkan hasil penelitiannya tentang negara terkorup di Asia di mata para pebisnis Asia, dimana Indonesia menjadi pemegang rekor diurutan pertama dengan skor 9,25, disusul negara India dengan skor 8,9, Vietnam 8,67, Filifina 8,35, Thailand, Malaysia dan Cina dengan skor 7,3 serta menempatkan Singapura dan Hongkong sebagai negara terbersih di Asia. ${ }^{26}$ Awal Juni 2005, lembaga yang sama juga mempublikasikan hasil penelitiannya tentang korupsi peradilan di Asia, hasilnya lagi-lagi Indonesia menempati posisi puncak dengan nilai 8,5 naik 0,4\% dari tahun sebelumnya 8,1.27 Kondisi yang terus memburuk ini jika dibiarkan dan tidak segera ditanggulangi bisa jadi suatu saat Indonesia akan menjadi negara paling korup di dunia.

Akhir-akahir ini, menurut Didin S.Damanhuri, pelbagai laporan, situasinya bahkan semakin memburuk, antara lain versi Survai The Political and Economic Risk Cunsultancy. Tahun 2005, lembaga ini mengungkapkan, dari 12 negara, Indonesia menempati peringkat ke 11 atau terburuk kedua setelah Vietnam. Sedangkan dalam rating risiko atau keamanan berbisnis, tergolong cukup tinggi. The Economist Intelligence Unit melaporkan skor Indonesia 86.28

Meski Indonesia memasuki era reformasi, namun relasi politik yang dimanifestasikan oleh partai politik adalah relasi yang bersifat paternalistik yang irrasional dan seringkali berdimensi hubungan simbolik primordial jangka pendek. Aktivitas politik di dalam partaipartai sudah lumrah didanai oleh praktek-praktek korupsi, kolusi dan nepotisme, seperti jual beli suara antar sesama pengurus partai pada forum pemilihan ketuanya atau pemilihan kepala daerah dan bahkan pada saat pemilihan umum. Akibat dari praktek dan perilaku politik

${ }^{25}$ Koran, Tempo, 10 Desember 2006.

${ }^{26}$ Surat Kabar, Suara Karya, tanggal 7 Maret 2005.

${ }^{27}$ Surat Kabar, Suara Karya, awal Juni 2005.

${ }^{28}$ Didin S. Damanhuri, Korupsi, Reformasi..., hlm. 12. yang korup tersebut, konstituen terancam kehilangan hak kontrol dan keterwakilan murni aspirasinya. Ketika konstituen tidak dapat mengontrol para wakilnya serta kehilangan keterwakilan aspirasinya, maka secara praktis para politisi akan dapat memutuskan apapun sesuai dengan selera koruptif sesaatnya. Kondisi demikian semakin diperparah dengan penerapan otonomi daerah yang sangat menekankan pada desentralisasi administratif dan finansial tanpa langkah-langkah yang programatis ke arah pemberdayaan aparat, masyarakat dan maksimalisasi peran serta di dalam pengambilan keputusan pada tingkat lokal atau upaya untuk lebih memaksimalkan kontrol mereka terhadap pelaksanaan keputusan itu sendiri. Dampaknya adalah desentralisasi hanya memperkuat dan lebih memperkokoh posisi elit lokal sementara publik secara umum tetap dalam kondisi kekurangan kapasitas dan pengalaman untuk terlibat $\mathrm{d}$ dalam proses-proses pengambilan kebijakan lokal. Hal ini mengindikasin bahwa masyarakat pada umumnya belum dapat menjadi kekuatan kritis sosial (social control) yang terorganisir. Selain dari itu, politik dan kultur birokrasi pemerintahan yang diciptakan dapat juga menjadi penyebab tersendiri bagi tumbuh suburnya korupsi. Gaji pegawai negeri sipil yang di bawah standard kebutuhan minimum, kurangnya antusiasme untuk menjadi pelayan publik yang efesien, praktek nepotis di dalam proses rekrutmen personil serta ketidakmampuan untuk membedakan antara hak dan kepemilikan publik dengan hak dan kepemilikan pribadi menjadi pemandangan kinerja birokrasi sehari-hari. Buruknya standard pelayanan publik itu semakin diperparah dengan sistem hukum yang cenderung belum secara optimal berpihak kepada proses pemberantasan korupsi. Aturan tentang akses kepada informasi publik masih terhalang oleh ketentuan tentang rahasia negara, belum ada jaminan undang-undang yang kuat tehadap pelapor kasus korupsi dan belum ada aturan yang jelas yang menjadi proses tuntutan publik di hadapan kekuatan birokrasi. Mengacu kepada SK Menteri Pendayagunaan Aparatur Negara Nomor 81 tahun 1993, pelayanan publik didefinisikan sebagai segala bentuk kegiatan pelayanan publik yang dilaksanakan oleh 
instansi pemerintah di tingkat pusat, daerah dan di lingkungan Badan Usaha Milik Negara dalam bentuk barang atau jasa, baik untuk memenuhi kebutuhan masyarakat maupun dalam rangka pelaksanaan ketentuan perundang-undangan. Pelayanan publik dalam kategori hak dasar, seperti pendidikan, kesehatan, jaminan sosial, jaminan keamanan, penyediaan air bersih (terutama bagi masyarakat marginal), harus menjadi tanggung jawab negara. Warga berhak mendapatkan pelayanan publik dasar dengan kualitas yang baik serta jaminan haknya. ${ }^{29}$

Dalam kaitan korupsi yang dilakukan oleh pejabat negara setidaknya didorong oleh faktor internal (aspek manusia) maupun eksternal (aspek sistem administrasi, kebijakan dan hukum). Aspek manusia antara lain adalah mentalitas yang bersumber dari kurangnya keimanan dan kadar ketakwaan, rendahnya etika dan moralitas para pejabat, sikap egoistis, tidak profesional, krisis kepemimpinan, rendahnya penghasilan, sikap hidup dan gaya hidup hedonistik, mendorong orang melakukan cara-cara illegal dan haram termasuk mengambil hak orang lain, menyalahi kewenangan jabatan dan menggunakan kas negara untuk keuntungan pribadi. Sedangkan faktor eksternal lebih terkait dengan sistem, antara lain, administrai yang buruk seperti peraturan perundang-undangan yang tidak realistis dan tidak akomodatif terhadap pencegahan korupsi, ketidakjelasan definisi dan standard operasi, prosedur yang berbelit-belit, kurangnya adanya transparansi, belum berlangsungnya pengawasan yang efektif, lemahnya sistem pengendalian interen yang berkorelasi positif dengan berbagai penyimpangan dan inefesiensi dalam pengelolaan kekayaan negara. ${ }^{30}$

\section{Korupsi Menurut Tasawuf Tahriki}

${ }^{29}$ Danang Widoyoko, dkk., Saatnya Warga Melawan ..., hlm. 2.

${ }^{30}$ Adiwarman Karim, Ekonomi Islam, Suatu Kajian Mikro, Jakarta: KBC, 2004), hlm. 47.
Shufisme dinamis sesungguhnya berbicara bagaimana mengembangkan opini dan sikap preventif agar seseorang tidak berperilaku eksesif dalam menyikapi harta kekayaan dan dunia yang mempesona. Tindak korupsi yang merupakan tindak melawan hukum dengan maksud memperkaya diri sendiri atau orang lain yang mengakibatkan kerugian perekonomian negara atau perusahaan, harus segera diberantas dari semua bidang dan sektor. Karena tindak korupsi mengakibatkan pembangunan ekonomi semakin terpuruk, mempersulit demokrasi dan tata pemerintahan yang baik (good governance). Di antara langkah-langkah yang harus dilakukan untuk membunuh tindak korupsi di bumi pertiwi ini, salah satunya adalah dengan cara memperbaiki citra dan jati diri manusia yaitu dengan memperbaiki sikap, pemikiran dan tingkah laku manusia sebagai ummat beriman, bertauhid dan bertashawwuf. Shufisme dinamis dapat dijadikan sebagai landasan moral dan etika, sebagai salah satu upaya preventif untuk menghindari tindak korupsi. Karena di dalam ajaran shufisme dinamis ditawarkan mengembangkan sikap positif terhadap dunia, baik di dalam politik, sosial, spiritual maupun ekonomi dan seni. Maknanya, shufisme dinamis dimaknai bukan berarti meninggalkan segalanya untuk berkhalwat, beruzlah, hidup zubud, qana'ah, tawakkul, shabar dan wara dalam interpretasi yang negatif. Begitu juga berperilaku shufi bukan berarti harus menjauhkan diri dari dunia nyata. Tashawnuf tabriki justru mengangkat kemampuan keshufian justru di dalam dunia, umpamanya mampu memposisikan kerja sebagai pengabdian yang tulus dan mendapatkan bimbingan pengalaman spiritual di tengah-tengah asyiknya sebuah jabatan dalam suatu pemerintahan dan kekuasaan, dengan kemampuan mengembangkan sikap positif secara dinamis tehadap dunia, hal itu adalah suatu prestasi yang cukup besar nilainya.

Dengan pemahaman shufisme dinamis mampu menuntun manusia melaksanakan ajaran Islam dengan sempurna dan mencapai al-insan al-kamil. Justru itu, tugas besar seorang muslim, mukmin dan mubsin, dalam memperoleh kebahagiaan hidup menegakkan hubungan 
sosial, bukan melalui 'uzlah dan khalwat yang ditakwilkan dan dipraktekkan secara pasif. Zuhud (asketik) selama ini difahami sebagai anti keduniaan, menjauhi kehidupan materi dan menganggap harta benda sebagai penghalang dalam ibadah. Namun, jika dicermati dalam sejarah shufi, tidak sedikit mereka yang hidup kaya, karena hasil dari penjualan buah karya mereka yang banyak dan sebagai pedagang, seperti Junaid al-Baghdadi (w.910 M), ${ }^{31}$ Muhyiddin al-Ghazali (10591111 M), ${ }^{32}$ Muhyiddin Ibnu Arabi (1165-1240 M) dan Abdurrahman Shiddiq al-Banjari (1857-1938 M dari Indragiri Hilir, Riau). ${ }^{33}$ Nabi Muhammad Saw sendiri sebagai pedagang dan pengembala kambing yang sukses serta penunggang kuda yang mahir. Justru itu, seharusnya difahami bahwa zuhud adalah anti keserakahan, ketamakan dan kemalasan. Zuhud berarti meninggalkan hal-hal yang menyebabkan jauh dari Allah, bukan meninggalkan dunia. Dengan demikian, zuhud dinamis dipratekkan oleh mereka yang bekerja keras dan ingin hidup kaya.

Murtadha Muthahhari mengemukakan prinsip utama zuhud menciptakan kebahagiaan dan kepuasan individu yang tidak dapat dipisahkan dari masyarakat, karena manusia secara emosional terikat dengan masyarakatnya dan mengemban tanggung jawab moral. Kebahagiaan individu tidak bisa terlepas dari kesejahteraan dan kedamaian sesama manusia. ${ }^{34}$ Dalam pandangan shufisme dinamis, seorang zahid memandang dunia dan akhirat saling terkait secara optimis. Dunia merupakan pintu menuju akhirat dan dunia adalah ladang akhirat. Esensi kebahagiaan dan kepuasan di akhirat terletak

${ }^{31}$ Laily Manshur, Ajaran dan Teladan Para Shufi, Jakarta: Raja Grafindo Persada, 1999), CetetakanI, hlm. 41.

${ }^{32}$ Abdul Aziz, Ekonomi Shufistik. Model al-Ghazali, Pemikiran al-Ghazali tentang Moneter dan Bisnis, (Jakarta: Wangsa Merta, 2004), Cetakan I.

${ }^{33} \mathrm{M}$. Arrafie Abduh, Corak Tasawuf..., hlm. 2.

${ }^{34}$ Rudhy Suharto, Revolusi Rubani, Refleksi Tashawwuf Pembebasan, Jakarta: Pustaka Intermasa, 2002), hlm. 100. pada pemenuhan komitmen dan tanggung jawab moral di alam dunia yang dilakukan dengan penuh kesadaran.

Menurut Imam Ahmad ibnu Hanbal (w.241 H) terdapat tiga tingakatan zuhud (awam, khawash dan arifin). Zuhud awam yaitu meninggalkan segala yang haram. Zuhud khawash yaitu meninggalkan hal-hal yang berlebihan dalam perkara yang halal. Sedangkan zuhud yang paling tinggi adalah tingkat arifin yaitu orang yang mampu meninggalkan apa saja yang dapat memalingkan diri dari Allah Swt. ${ }^{35}$ Dari tingkatan zuhud tersebut dapat ditangkap nilai-nilai yang kondusif untuk upaya menyirnakan kemiskinan, menanggalkan hal-hal yang haram, menuntun orang mencari kekayaan secara tulus lewat kerja keras, menghindari suap menyuap dan menciptakan lapangan pekerjaan untuk mengurangi pengangguran. Dalam kaitan zuhud dalam Islam, apa yang ditemui Max Weber (1864-1920 M) tidak ada kapitalisme di Timur, tidak ada etika asketis di dalam Islam, dikecam keras oleh Bryan S.Turner, dalam karyanya Sosiologi Islam, suatu Telaah Analitis atas Tesa Sosiologi Weber, seolah-olah ia ingin menciptakan The Islamic Ethic and the Spirit of Capitalism (Etika Islam dan Semangat Kapitalisme), sebagai kembaran dari karya monumental Max Weber The Protestant Ethic and the Spirit of Capitalism. ${ }^{36}$ Semangat kapitalisme itu bersandarkan kepada cita ketekunan, hemat, berperhitungan, rasional dan sanggup menahan diri. ${ }^{37}$ Maxim Rodinson, dalam karyanya Islam and Capitalism, kecewa karena sebenarnya ia merasa bahwa Islam memiliki semacam superioritas

35Jalaluddin Rahmat, Islam Alternatif, Ceramah di Kampus-Kampus, (Bandung: Mizan, 1991), Cetakan IV, hlm. 99.

${ }^{36}$ Bryan S. Turner, Weber and Islam, diterjemahkan oleh G. A. Ticoalu, Sosiologi Islam, Suatu Telaah Analitis atas Tesa Sosiologi Weber, (Jakarta: Rajawali, 1992), Cetakan III, hlm. vi.

${ }^{37}$ Taufik Abdullah, editor, Agama, Etos Kerja dan Perkembangan Ekonomi, (Jakarta: Yayasan Obor, 1988), Cetakan IV, hlm. 8. 
dalam ajarannya, tapi superioritas itu tidak muncul dalam kehidupan empiris. ${ }^{38}$

Sikap lain yang menunjang mentalitas anti korupsi adalah qana'ah. Qana'ah dalam shufisme sering difahami sebagai sikap nrimo yaitu mudah menyerah dan menerima apa adanya, tanpa usaha maksimal. Tuntutan untuk kemajuan dianggap sebagai hal yang tidak begitu perlu, karena bertentangan dengan sikap nrimo. Pemahaman seperti itu jelas keliru. Qana'ah dalam pandangan shufisme dinamis difahami sebagai sikap yang tulus untuk menerima hasil sesuai dengan kerja yang dilakukan, tidak serakah, tidak menuntut hasil yang lebih banyak dengan kerja yang kecil, tidak hasad dan tidak mengkhayal. Produktivitas sesuai dengan kemampuan dan tingkat kerja yang dilakukan, itulah makna qana'ah. Justru itu, qana'ah adalah salah satu sikap untuk menjadi kaya, namun belum tentu dapat diamalkan oleh orang miskin.

Sikap lainnya yang mendukung anti korupsi adalah tawakkul (sering ditulis tawakkal, mungkin salah kafrah, tapi yang benar menurut penulis adalah tawakkul, mashdar dari tawakkala, yatawakkalu dan tawakkulan). Tawakkul dalam shufisme juga sering diidentikkan dengan sikap pasrah dan tanpa usaha keras (fatalis). Pemahaman demikian jelas keliru. Justru itu, tawakkul seharusnya difahami sebagai sikap akhir setelah bekerja dan berusaha keras secara maksimal yang dilakukan berulang kali sebelum behasil. Setelah berusaha keras, maka dengan bekal tauhid, fikih dan tashawwuf, keberhasilan akhirnya tidak selalu ditentukan oleh dirinya sendiri. Dengan sikap tawakkul akan terhindar dari sikap frustrasi, depressi dan stress. Adalah sangat keliru kalau menempatkan sikap tawakkul sebelum adanya upaya maksimal.

Selain dari itu, sikap anti korupsi yang cukup besar andilnya memiliki sifat shabar. Makna shabar sering diidentikkan dengan sikap

${ }^{38}$ Maxim Rodinson, Islam and Capitalism, alih bahasa Asep Hikmat, Islam dan Kapitalisme, (Bandung: Iqra, 1982), Cetakan I, hlm. 2. lamban. Padahal seharusnya, shabar difahami sebagai sikap tangguh, pantang menyerah, teliti, cermat dan ulet, sehingga tidak mudah menyerah dan putus asa. Shabar adalah sikap mampu menahan derita dalam perjuangan untuk meraih sukses. Jika shabar diartikan lamban tidak sesuai dengan firman Allah, artinya, Sesungguhnya Allah menyukai orang-orang yang shabar (surah Ali Imran ayat 146). Dalam salah satu bait syairnya, Abdurrahman Shiddiq al-Banjari mengemukakan:

Ridhakan olehmu qadha Allah

Syukur olehmu nikmat Allah

Shabar olehmu bala dan susah

Haram jikalau mengeluh kesah. ${ }^{39}$

Selain dari zuhud, qana'ah, tawakkul dan shabar, wara' adalah salah satu sikap moral yang besar muatan motivasi dan dinamisasinya dalam menahan lajunya arus korupsi. Seseorang yang bersikap wara' selalu berupaya menjauhkan diri dari sesuatu masalah yang belum ada kepastian hukum halal atau haramnya. Untuk menyikapi di antara dua hal yang meragukan ini, maka shufisme dinamis mengambil langkah menjaga diri dari kedua perkara tersebut agar tidak terjerumus ke dalam syubhat.

Jika prinsip dan ajaran yang ditawarkan oleh shufisme dinamis berpadu dengan sikap ekonomis yang dinamis dengan tujuan ingin memperbaiki moral individu, masyarakat dan bangsa, dalam rangka membentuk pemerintahan yang baik, maka konidisi ini akan memunculkan suasana kondusif untuk mewujudkan para pelaku bisnis berdasi yang jujur, kaya, dan menjunjung tinggi moral, dengan mentawazzunkan ibadah mahdhah dan ibadah sosial. Selain dari itu, situasi ini mewujudkan kifrah tata pemerintahan yang bersih dan berwibawa. Justru itu, tindak korupsi yang menyengsarakan rakyat miskin terutama, dapat diminimalisir terutama di bumi Melayu ini.

${ }^{39}$ Abdurrahman Shiddiq al-Banjari, Sya'ir Ibarat Khabar Qiamat Menuju Keinsafan, (Singapura: Maktabah Ahmadiyyah, 1344 H), hlm. 16 
Salah satu metode (thariqah) menurut shufisme dinamis untuk melakukan pemberantasan terhadap korupsi, kolusi dan nepotisme adalah menekankan korupsi merupakan suatu perwujudan syirik, karena korupsi telah menjadi virus dan kanker ganas yang menjalar hampir ke semua bidang dan sektor kehidupan. Korupsi merupakan penyakit jiwa dan moral hazard yang harus diobati melalui psikoterapi shufistik (dinamis). Konteks syirik tidak dapat lagi hanya berbicara pada pengakuan terhadap qadim atau hadisnya al-Qur`an, halal atau baram, baik atau buruk, seperti yang diperdebatkan mutakallimin, filosof, modernis dan shufi, namun harus mempersoalkan hal yang terkait dengan kehidupan ekonomi, sosial, politik dan seni. Syirik memang perlu diberi tafsir dinamis. Dualisme tentang Tuhan dilihat dari tingkat kerusakan publik dan lingkungan serta penderitaan manusia yang berkepanjangan, memperkuat perspektif bahwa korupsi menjadi salah satu perbuatan syirik. Korupsi juga termasuk perbuatan dosa dan fasad yaitu suatu perbuatan yang merusak tatanan kehidupan yang pelakunya harus dibunuh atau disalib, sesuai dengan tingkat besarnya perbuatan nyata korupsi yang dilakukan koruptor, misalnya, melakukan korupsi senilai satu trilyun lebih harus dieksekusi, atau dipotong tangan dan kaki mereka dengan cara menyilang bila melakukan korupsi senilai satu milyar lebih, atau diusir dari negeri (tempat kediamannya), bila melakukan korupsi senilai seratus juta lebih.

\section{Kesimpulan}

Tindakan korupsi menurut shufisme dinamis perlu disadari sebagai perbuatan yang lebih buruk daripada teroris, karena dampak yang ditimbulkan dari perbuatan korupsi ternyata tidak dapat dipangkas dalam hitungan waktu (jam, hari, bulan dan tahun). Penyimpangan korupsi terjadi secara massif, berbeda dengan perbuatan teroris yang hanya dilakukan oleh seseorang atau sekelompok orang. Sebagai dampak yang lebih besar adalah korupsi melahirkan penderitaan dan kemiskinan struktural dan kultural yang berkepanjangan karena banyak hak-hak sipil dirampas. Melukis wajah zahid shufi, Di atas kanvas serban kaci, Shufisme dinamis harus mandiri, Menghindari nepotisme dan korupsi.

\section{Bibliografi}

Abduh, M.Arrafie, Corak Tashamnuf Abdurrabman Shiddiq dalam SyairSyairnya, (Pekanbaru: Suska Press, 2008).

Abdullah,Taufik, editor, Agama, Etos Kerja dan Perkembangan Ekonomi, (Jakarta: Yayasan Obor, 1988).

Alatas, Syed Husein, Korupsi; Sifat, Sebab dan Fungsi, (Jakarta: Dzikrul Hakim, 1997).

Al-Jurjani, Ali ibnu Muhammad, Kitab al-Ta'rifat, (Beirut: Maktabah Lubnan, 1978).

Al-Munawi, M.Abdu al-Rauf, al-Tawqif 'ala Mubimmati al-Ta'rif, (Beirut: Dar al-Fikr, 1410 H/1990 M).

Aziz, Abdul, Ekonomi Shufistik Model al-Ghazali, Pemikiran al-Ghazali tentang Moneter dan Bisnis, (Jakarta: Wangsa Merta, 2004).

Azizy, A.Qodri, Cara Kaya dan Menuai Surga, (Jakarta; Renaisan, 2005).

Baalbaki, Rohi, al-Mawrid, A Modern Arabic-English Dictionary, (Beirut: Dar el-Ilm Lilmalayin, 2000).

Badudu, J.S., dan Sutan Mohammad Zain, Kamus Umum Bahasa Indonesia, (Jakarta: Pustaka Sinar Harapan, 1994).

Binawan, L. dan Al.Andang, editor, Korupsi Kemanusiaan, Menafsirkan Korupsi (dalam) Masyarakat, (Jakarta: Kompas Media Nusantara, 2006).

Buletin Anti Korupsi, Partnership, Desember 2004.

Damanhuri, Didin S., Korupsi, Reformasi dan Masa Depan Ekonomi Indonesia, Jakarta: Lembaga Penerbit Fakultas Ekonomi Universitas Indonesia, 2006). 
Al-Fikra: Jurnal Ilmiah Keislaman, Vol. 10, No. 2, Juli Desember 2011

Dawud, Abu, Sunan Abi Dawud, (Beirut: Dar al-Hadis, 1393).

Ibnu Hanbal, Ahmad, Musnad Ahmad, (Beirut: Dar al-Kutub al'Ilmiyyah, 1412 H/1992 M).

Iqbal, Sir Muhammad, Islam and Abmadism, penerjemah Machnun Husein, Islam dan Abmadiyyah, Jawaban terhadap PertanyaanPertanyaan Pandit Jawaharlal Nehru, Cetakan I, Jakarta: Bumi Aksara, 1991).

Karim, Adiwarman, Ekonomi Islam, Suatu Kajian Mikro, (Jakarta: KBC, 2004).

Komisi Pemberantasan Korupsi, Mengenali dan Memberantas Korupsi, (Jakarta: KPK, 2006).

Majalah, Tempo, 10 Desember 2006.

Laily Manshur, Ajaran dan Teladan Para Shufi, (Jakarta: Raja Grafindo Persada, 1999).

Majah, Ibnu, Sunan Ibnu Majah, Muhaqqiq Muhammad Fuad 'Abd alBaqi, Juz II., (Beirut: Dar al-Ihya` al-Turats al-'Arabi, t.t.).

Marpaung, Leden, Tindak Pidana Korupsi, (Jakarta: Djambatan, 1989).

Masodang, M. Saleh, dan Andyana, JB., Kamus Umum Indonesia-Jepang, (Bandung: Pioner Jaya, 1986).

Munawwir, A.W., Kamus al-Munawwir Arab-Indonesia Terlengkap, (Krapyak: Pondok Pesantren al-Munawwir, 1984).

Nadjib, Emha Ainun, Kafir Liberal, (Yogyakarta: Proggress, 2005).

Nasution, Harun, Falsafat dan Mistisisme dalam Islam, Cetakan II, (Jakarta: Bulan Bintang, 1978).

, Islam Ditinjau dari Berbagai Aspeknya, Jilid II., (Jakarta: Universitas Indonesia, 1986).

Otto, Rudolf, Mysticism East and West, A Comparative Analysis of The Nature of Mysticism, A Discussion of the Nature of
M. Arrafie Abduh, Tasanuf Tahriki: Anti Korupsi

Mysticism, transleted by Bertha L.Bracey and Richenda C.Payne, (New York: The Micmillan Company, 1972).

Rahmat, Jalaluddin, Islam Alternatif, (Bandung: Mizan, 1991).

Redaksi Penerbit Asa Mandiri, Undang-Undang Pemberantasan Tindak Pidana Korupsi, (Jakarta: Asa Mandiri, 2007).

Rodinson,Maxim, Islam and Capitalism, alih bahasa Asep Hikmat, Islam dan Kapitalisme, (Bandung, Iqra, 1982).

Salim, Peter dan Salim, Yenny, Kamus Bahasa Indonesia Kontemporer, (Jakarta: Modern English Press, 1991).

Shiddiq al-Banjari, Abdurrahman, Sya'ir Ibarat Khabar Qiamat Menuju Keinsafan, (Singapura: Maktabah Ahmadiyyah, 1344 H).

Smith, Walfred. C., Modern Islam in India, (Lahore: Asyraf, 1963).

Suharto, Rudhy, Revolusi Rubani, Refleksi Tashawnuf Pembebasan, (Jakarta: Pustaka Intermasa, 2002).

Surat Kabar, Kompas, tanggal 25 Mei 2003 dan 21 Oktober 2004.

Surat Kabar, Suara Karya, tanggal 7 Maret dan awal Juni 2005.

Tirtobisono, Yan, Kamus Inggris-Mandarin-Indonesia, (Surabaya: Indah, 1996).

Turner, Bryan S, Weber and Islam, diterjemahkan oleh G.A.Ticoalu, Sosiologi Islam, Suatu Telaah Analitis atas Tesa Sosiologi Weber, (Jakarta: Rajawali, 1992).

Widoyono, Danang, dkk., Saatnya Warga Melawan Korupsi; Citizen Report Card untuk Pendidikan, (Jakarta: Indonesia Corruption Watch, 2006).

Wehr, Hans, A Dictionary of Modern Written Arabic, (Beirut: Libraire du Liban, 1980).

Zainuri, Achmad, Akar Kultural Korupsi di Indonesia, (Depok: CV.Cahaya Baru Sawangan, 2007). 